\title{
Food habits of two syntopic canids, the maned wolf (Chrysocyon brachyurus) and the crab-eating fox (Cerdocyon thous), in southeastern Brazil
}

\author{
Hábitos alimentarios de dos cánidos sintópicos, el aguara guazú (Chrysocyon brachyurus) \\ y el zorro del monte (Cerdocyon thous), en el sudeste de Brasil
}

ADRIANA DE ARRUDA BUENO \& JOSÉ CARLOS MOTTA-JUNIOR

Laboratório de Ecologia Trófica, Departamento de Ecologia, Instituto de Biociências da Universidade de São Paulo, São Paulo, 05508-900, Brasil; e-mail: abueno@ib.usp.br

\begin{abstract}
The maned wolf (Chrysocyon brachyurus) and the crab-eating fox (Cerdocyon thous) are two South American canids with large overlap in their geographic distribution. However, there are few data on the comparative ecology of these species. The aim of this research was to quantify the diet of these two canids living in syntopy at three levels: frequency of occurrence, minimum number of individuals preyed and estimated biomass ingested. Additionally, seasonality in the consumption of major groups of food items and aspects of prey size distribution were assessed. The study took place in the Experimental Station of Itapetininga, São Paulo State, Brazil. General results showed that both canids are omnivorous in accordance with other studies. By occurrences, the wolves consumed vegetal and animal food in similar proportions, whereas the foxes consumed more animals, mainly insects. In contrast, both canids ingested mainly animal food if biomass is considered. The maned wolf consumed more wolf's fruit (Solanum lycocarpum) and small mammals in the dry season, and miscellaneous fruits during the wet season. The crab-eating fox also ingested more miscellaneous fruits in the wet season, but the insects were mostly consumed during dry months. The crabeating fox is more generalist than the maned wolf, but the wolf seems better able to handle distinct prey types. The distribution of prey sizes suggested separate food niches: while the maned wolf consumed a larger spectrum of prey sizes, especially small vertebrates between 10.1 and $100.0 \mathrm{~g}$, the crab-eating fox consumed smaller prey, mainly insects between 0.01 and $0.1 \mathrm{~g}$.
\end{abstract}

Key words: Chrysocyon brachyurus, Cerdocyon thous, Brazil, diet, syntopy.

\section{RESUMEN}

El aguara guazú (Chrysocyon brachyurus) y el zorro del monte (Cerdocyon thous) son dos cánidos sudamericanos cuyas distribuciones geográficas se sobreponen extensamente. Sin embargo, hay pocos datos sobre la ecología comparativa de estas especies. El objetivo de esta investigación fue cuantificar la dieta de estos dos cánidos en sintopia en cuanto a tres niveles: frecuencia de ocurrencia, número mínimo de individuos depredados y biomasa ingerida estimada. Además, se evaluaron la estacionalidad en el consumo de grupos de presas mayores y la distribución de tamaño de las presas consumidas. El estudio tuvo lugar en la Estación Experimental de Itapetininga, en el Estado de São Paulo, Brasil. Los resultados mostraron que ambos cánidos son omnívoros. El aguara guazú consumió partes vegetales y animales en proporciones similares, pero los zorros consumieron más presas animales, principalmente insectos. En relación a la biomasa de las presas, ambas especies consumieron presas animales. El aguara guazú consumió muchos frutos de Solanum lycocarpum y micromamíferos en la estación seca, mientras que los frutos misceláneos dominaron la dieta durante la estación lluviosa. El zorro del monte también ingirió más frutos misceláneos en la estación lluviosa, mientras que los insectos fueron principalmente consumidos en los meses secos. El zorro es más generalista que el aguara guazú, pero en lo que se refiere a habilidades de captura, el aguará parece ser capaz de manipular más tipos de presas y frutos diferentes. La distribución de tamaños de las presas consumidas sugiere una separación de nicho trófico entre ambas especies: mientras que el aguara guazú consumió un espectro más amplio de tamaños de presas, especialmente los vertebrados pequeños entre 10,1 y 100,0 g, el zorro consumió presas más pequeñas, principalmente insectos entre 0,01 y $0,1 \mathrm{~g}$.

Palabras clave: Chrysocyon brachyurus, Cerdocyon thous, dieta, Brasil, sintopia. 


\section{INTRODUCTION}

The maned wolf (Chrysocyon brachyurus Illiger, 1815) and the crab-eating fox (Cerdocyon thous Hamilton Smith, 1839) are two sympatric South American canids with large overlap in their geographical distribution. The maned wolf $(20-26 \mathrm{~kg})$ inhabits mostly savannah-like and grasslands habitats in Central South America, including most Paraguay, northeastern Argentina, northwestern Uruguay, southeastern Peru and large parts of central-east Bolivia and central-south Brazil (Langguth 1975, Dietz 1985, Mones \& Olazarri 1990, Nowak 1999). The crab-eating fox (4-7 $\mathrm{kg}$ ) can be found in Colombia, Venezuela, Guyana, Surinam, eastern Peru, Bolivia, Paraguay, Uruguay, northern Argentina and most of Brazil, outside the lowlands of the Amazon Basin, mostly in forests, forest edges, wooded savannahs and open woodland areas (Langguth 1975, Berta 1982, Nowak 1999). The maned wolf is included in the IUCN Red List as a "lower risk - near threatened" species (Hilton-Taylor 2000), and in the Brazilian official list as a "threatened" species (Bernardes et al. 1990). Although the crabeating fox is not endangered with extinction, this canid is on Appendix II of CITES (Nowak 1999) as a vulnerable species.

Besides differences in the size of these canids, their ecology is also distinct. Except during the breeding season, the maned wolf is a solitary animal, and its activity is mainly crepuscular to nocturnal (Dietz 1984, 1985). Its home range is large, varying from 21.7 to 115.0 $\mathrm{km}^{2}$ (Dietz 1984, 1985, Carvalho \& Vasconcellos 1995, Rodrigues et al. 1998). The crab-eating-fox has a smaller home range, varying from 5 to $10 \mathrm{~km}^{2}$ (Mcdonald \& Courtenay 1996, Nowak 1999). It is mostly nocturnal, travels in pairs, but hunts individually (Brady 1979, Berta 1982, Mcdonald \& Courtenay 1996, Nowak 1999). Both species are omnivorous, consuming fruits, small mammals, insects, birds and reptiles, among others, and exhibit seasonality in the consumption of some food items (Brady 1979, Bisbal \& Ojasti 1980, Dietz 1984, Motta-Junior et al. 1994, Mcdonald \& Courtenay 1996, Facure \& Monteiro-Filho 1996, Facure \& Giaretta 1996, Juarez \& Marinho-Filho 2003, Aragona \& Setz 2001, Bueno et al. 2002).

The lack of quantitative studies about diet of South American canids needs to be fulfilled (Medel \& Jaksic 1988, Motta-Junior et al. 1996). Only a few studies have reported the feeding habits of these carnivores (e.g., Juarez
\& Marinho-Filho 2003, Motta-Junior et al. 1996, Bueno et al. 2002). Moreover, few comparative studies on the feeding ecology of canids are available (e.g., Olmos 1993, Facure \& Giaretta 1996, Juarez \& Marinho-Filho 2003). During this study, we aimed at comparing the food habits of these two syntopic canids at three levels. In particular, we quantified the frequency of occurrence as a function of all occurrences (Dietz 1984), the minimum number of individual prey taken (Emmons 1987), and estimated consumed biomass (Emmons 1987, Motta-Junior et al. 1996). Additionally, seasonality in the consumption of major groups of food items and prey size distribution were assessed.

\section{MATERIAL AND METHODS}

We conducted the research in the Experimental Station of Itapetininga, São Paulo State, southeast Brazil $\left(23^{\circ} 42^{\prime} \mathrm{S}, 4^{\circ} 57^{\prime} \mathrm{W}\right)$ with an area of 6,706 ha. The average elevation is 645 $\mathrm{m}$ and the climate is within Köppen's Cfa, hot with a dry winter, and exhibiting wet (October to March) and dry (April to September) seasons. Nearly half of the area is covered with Pinus spp. and Eucalyptus spp. plantations, whereas savannahs (locally named "campo cerrado"), marshes, and gallery forests dominated the rest of the area.

We searched monthly for faecal samples in roads and trails from March 1998 to December 1999. Faeces of each canid were identified by appearance, odour, location, fur and associated tracks. The faecal samples were taken to the laboratory where they were washed in water through a fine mesh screen $(1 \mathrm{~mm})$ (Emmons 1987, Motta-Junior et al. 1996). Afterwards, they were oven-dried $\left(60^{\circ} \mathrm{C}\right)$ for $24 \mathrm{~h}$.

Remains of teeth, bones, fur, bills, feathers, scales, and seeds were identified by comparison with a reference collection, and by assessment of museum specialists. Hard parts of prey were used to count the minimum number of individuals consumed (Emmons 1987). Ingested prey biomass was estimated by counting the minimum number of individuals in faeces and then multiplying this number by the mean body mass of each species at the study site (Emmons 1987). The average number of seeds and weight per fruit species were obtained in the field to estimate the number of fruit and biomass ingested by the canids (Castro et al. 1994, Motta-Junior et al. 1996). Body masses of snakes were estimated from the width of the largest ventral 
scale found in faeces after using a regression equation (Appendix 1). We assumed complete ingestion of prey when teeth, claws and bones of all parts of the skeleton were found in the faeces, including large prey such as armadillos (Motta-Junior et al. 1996). Whenever we identified the size, but not the species of some small mammals, we estimated biomass based on the average body mass of known species of similar size.

We used contingency tables and G-tests (Zar 1984) to verify whether prey types did vary according to season of the year. The number of major prey used in the analysis were nine and seven for the maned wolf and the crab-eating fox, respectively. The Levins's standardised niche breadth index $\left(\mathrm{B}_{\mathrm{A}}\right)$ was employed to analyse the quantitative distribution of each prey in the diet (Krebs 1999), both at the level of species/ morphospecies and at broad categories of prey (fruits, grasses, fishes or frogs, insects, lizards, snakes, birds, armadillos, small mammals and medium/large mammals). Frogs were considered for the fox only, whereas fishes were included in the case of the maned wolf exclusively. These large prey categories were chosen based on that each type of prey needs different detection abilities, foraging techniques, and capture methods by the predator (Jaksic et al. 1992). Therefore, high $\mathrm{B}_{\mathrm{A}}$ values would suggest more skilled handling of different prey types.

\section{RESULTS}

The study was based on the analysis of 483 and 78 faeces from the maned wolf and the crabeating fox, respectively. A total of 1,344 occurrences distributed in 74 identified prey and fruit items were analyzed for the wolves, 22 corresponding to plant and 52 to animal material. The diet of foxes yielded 429 occurrences in 95 different food items, 17 of which were vegetal and 78 were animal items (Appendix 1).

By occurrence, the wolves consumed plant and animal food in similar proportions (Table 1). The crab-eating fox was also omnivorous, although the consumption of animals was higher than that of vegetal items (Table 1). Miscellaneous fruits and small mammals were the most consumed items in the wolf's diet, whereas insects (Coleoptera, $22.1 \%$ and Orthoptera, $14.7 \%$ ) and miscellaneous fruits were highly consumed by the foxes (Table 1 ).

By biomass, the maned wolf showed a diet heavily based on the consumption of animals. Armadillos and small mammals were the most important items totalling $50.9 \%$ (Table 1). In the case of foxes, the bulk of their diet was based on the consumption of animal material, especially medium to large mammals (50.3 $\%)$. Miscellaneous fruits were also important items (Table 1).

TABLE 1

Occurrence and biomass of major groups of food items found in 438 and 78 scats of the maned wolf and the crab-eating fox, respectively, collected in Itapetininga, southeastern

Brazil. Values are percentages. Totals are number of occurrences and biomass in grams

Ocurrencia y biomasa de los mayores grupos de presas y frutos encontrados en las 438 y 78 heces del aguara-guazú y del zorro del monte, respectivamente colectados en Itapetininga, sudeste de Brasil. Los valores son porcentajes. Los totales son número de ocurrencias y biomasa en gramos

\begin{tabular}{lcrrr}
\hline Food item & \multicolumn{2}{c}{ Chrysocyon brachyurus } & \multicolumn{2}{c}{ Cerdocyon thous } \\
\cline { 2 - 3 } & Occurrence & Biomass & & Occurrence \\
\hline Solanum lycocarpum fruits & 17.1 & 11.8 & 2.5 & 1.6 \\
Miscellaneous fruits & 27.0 & 10.1 & 14.0 & 19.0 \\
Grasses & 13.3 & tr & 21.9 & 0.0 \\
Subtotal plants & 57.4 & 0.1 & 21.4 & 20.6 \\
Insects & 7.1 & 5.1 & 60.1 & 3.0 \\
Snakes, lizards, frogs and fishes & 1.5 & 31.3 & 4.0 & 7.4 \\
Birds & 9.9 & 19.6 & 0.5 & 3.2 \\
Armadillos & 2.6 & 16.7 & 8.9 & 21.4 \\
Small mammals & 20.4 & 78.1 & 0.7 & 15.4 \\
Medium and large mammals & 1.1 & 78.6 & 29.0 \\
Subtotal animals & 42.6 & $230,208.2$ & 429 & 79.4 \\
Total & 1,344 & & $18,660.3$ \\
\hline
\end{tabular}

(tr) value below $0.05 \%$ 
The diet of crab-eating foxes varied with season $\left(\mathrm{G}_{6}=54.0, \mathrm{P}<0.0001\right)$. While miscellaneous fruits were present in the diet mainly during the wet months, insects (mostly Orthoptera) were consumed mostly in the dry ones (Fig. 1A). The maned wolf's diet was also dependent on the season $\left(\mathrm{G}_{8}=160.7, \mathrm{P}<\right.$ 0.0001). Wolf's fruit (S. lycocarpum) and small mammals were present in the diet mainly in the dry season, whereas miscellaneous fruits were more consumed in the wet season (Fig. 1B). All the other items were consumed in similar proportions in both seasons by the two canids.

The crab-eating fox was a generalist carnivore $\left(\mathrm{B}_{\mathrm{A}}=0.698\right)$ when taking into consideration 95 different food items, whereas the maned wolf was relatively more specialist $\left(\mathrm{B}_{\mathrm{A}}=0.235, \mathrm{n}=74\right.$ food items $)$. In contrast, when food items were classified into ten different prey categories, foxes were relatively more specialized $\left(\mathrm{B}_{\mathrm{A}}=0.165, \mathrm{n}=10\right)$ than the wolves $\left(\mathrm{B}_{\mathrm{A}}=0.281, \mathrm{n}=10\right)$.

Not only did the maned wolf include a larger spectrum of prey size in its diet (from $0.02 \mathrm{~g}$ to $16,300.0 \mathrm{~g}$ ), but it also consumed heavier prey than the crab-eating fox (from $0.02 \mathrm{~g}$ to $2,700.0 \mathrm{~g}$ ) (see Fig. 2). In spite of its larger size, the maned wolf consumed mostly small vertebrates between 10.1 and $100.0 \mathrm{~g}$ (57.1\% of 929 individuals), small mammals being the bulk of the animal prey (Fig. 2). The crab-eating fox consumed mainly insects up to $0.1 \mathrm{~g}(74.7 \%$ of 2,916 individuals, Fig. 2).

\section{DISCUSSION}

Several studies have pointed out the consumption of fruits and small mammals by the maned wolf (Dietz 1984, Motta-Junior et al. 1996, Aragona \& Setz 2001, Bueno et al. 2002), and they were important food resources in our study site. The high occurrence of vegetal material could be understood not only by the consumption of fruits, but also by the great occurrence of grass leaves (Table 1), which may improve the efficiency of digestion (Dietz 1984).

Several studies quantified the crab-eating foxes's diet by means of different methodologies, including direct observation (Montgomery \& Lubin 1978, Brady 1979), stomach contents (Bisbal \& Ojasti 1980, Facure \& Monteiro-Filho 1996), and faecal samples (Motta-Junior et al. 1994, Macdonald \& Courtenay 1995, Facure \& Giareta 1996, Juarez \& Marinho-Filho 2003). However, all reported ingestion of similar food items, although in varying proportions. In this study, the high consumption of animal material was due to the high number of occurrences of insects (Table 1). These invertebrates were already found by other authors in the diet of foxes (Motta-Junior et al. 1994, Macdonald \& Courtenay 1995, Facure \& Giareta 1996, Juarez \& MarinhoFilho 2003), but at lower frequencies. The use of insects may be caused by a large abundance of this food resource in our study site.
(A) Cerifocyon rhows

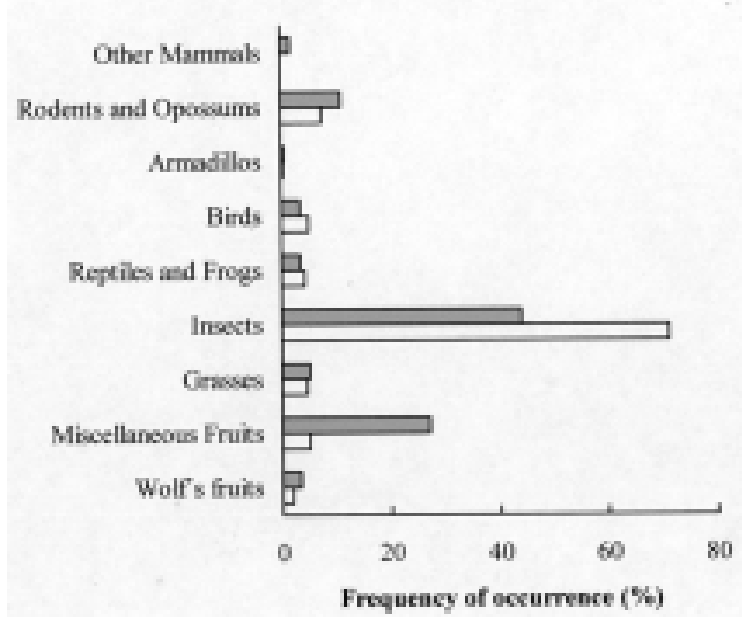

(B) Chrysocene brachyurses

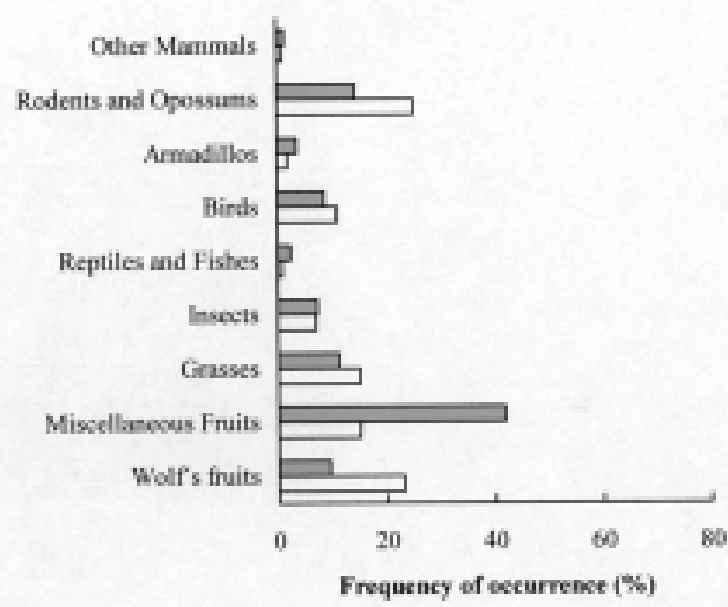

Fig. 1: Consumption of food items in the dry (white bars) and rainy (grey bars) seasons by $C$. brachyurus (205 and 278 faeces, respectively) and $C$. thous (32 and 46 faeces, respectively).

Consumo de presas en las estaciones seca (barras blancas) y lluviosa (barras grises) por C. brachyurus (205 y 278 heces, respectivamente) y C. thous (32 y 46 heces, respectivamente). 


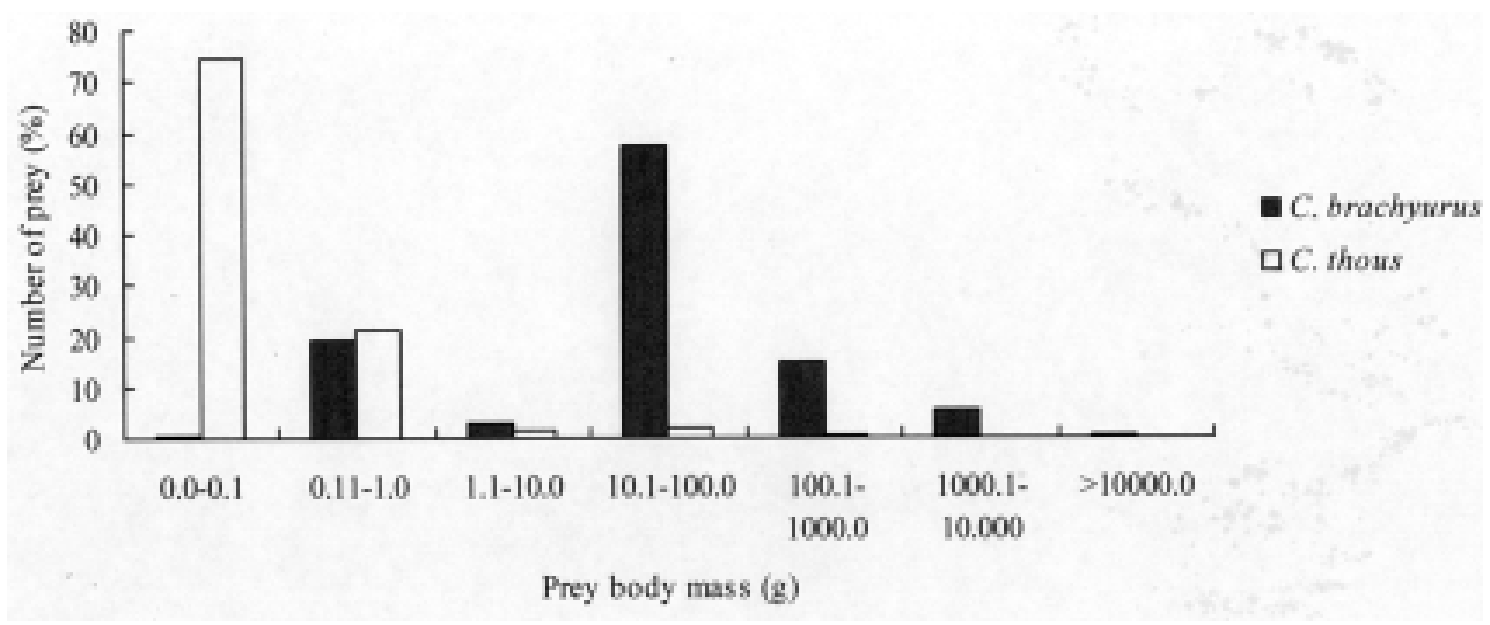

Fig. 2: Percentage of total number of animal prey found in faeces of maned wolf ( $\mathrm{n}=929$ prey) and crab-eating fox ( $\mathrm{n}=2,916$ prey), as a function of prey body mass.

Porcentaje del número total de presas animales registradas en las heces del aguara-guazú $(\mathrm{n}=929$ presas $)$ y del perro del monte $(\mathrm{n}=2.916$ presas $)$, en función de la masa corporal.

Concerning biomass, animal prey constituted the basis of the diet of both canids. The high incidence of animal biomass in the maned wolf's diet was in accordance with previous studies (Bueno et al. 2002). Remains of Mazama sp. (Artiodactyla) found in faeces at the study site showed that the maned wolf may take large prey occasionally, a finding previously reported (e.g., Motta-Junior et al. 1996). We are not certain whether the wolf preyed on the animal or consumed its carcass. Active predation of large ungulates by the maned wolf has been observed in central Brazil (Bestelmeyer \& Westbrook 1998).

Estimates of biomass consumption by crabeating foxes are rare (Juarez \& Marinho-Filho 2003). Differences between these previous studies and our results suggest an opportunistic behavior by the crab-eating fox, with a broad diet and flexible habitat preferences (Brady 1979, Bisbal \& Ojasti 1980, Berta 1982, MottaJunior et al. 1994, Facure \& Monteiro-Filho 1996). Because complete ingestion of prey was assumed, the high estimated biomass for medium and large mammals might be an overestimate. However, we suggest that mammalian prey constitutes the basis of foxes's diet in terms of biomass.

One of the most distinct differences in the diet of these two carnivores lies in the high incidence of insects, a prey scarcely consumed by the maned wolf (Table 1, Dietz 1984, Juarez \& Marinho-Filho 2003). These findings are in accordance with Eisenberg \& Redford (1992), who found a correlation between body size and diet of South American canids where smaller species ate more arthropods. It is interesting that wolves consumed wasps (Vespidae), including varying proportions of nests and honey, an observation reported in other areas (Langguth 1975, Motta-Junior 2000). The ingestion of Vespidae nests by wolves could be ecologically equivalent to the consumption of fruits, as suggested by Motta-Junior (2000); wolves were probably more interested in the honey inside of nests than in the wasps.

The seasonality in the consumption of fruits and small mammals by both canids may reflect different phenologies and changes in the abundance of food items during our study. For instance, the maned wolf seemed to switch from wolf's fruits to other wild fruits, which kept this type of prey item present in the diet throughout the year, as reported in other areas (Motta-Junior 2000; Motta-Junior \& Martins 2002). The high consumption of fruits in the wet season by foxes was reported previously by Motta-Junior et al. (1994).

When all species/morpho-species are taken into consideration, the wolves are more specialized, probably due to the consumption of wolf's fruits $(17.1 \%)$ and grasses $(13.3 \%)$. They seem to consume few food resources in high frequencies and many food items in low frequencies. The analysis by groups showed a specialisation in capture/handling abilities for the foxes caused by a high consumption of insects (Table 1), which was higher during the 
dry season (Fig. 1). Therefore, wolves seem to be using different capture abilities in more similar frequencies than the crab-eating fox.

The distribution of prey sizes suggested segregation in the food niches of both carnivores, and supported Rosenzweig (1966) who reported a trend towards an increase in food size with body size across Carnivora. Indeed, body size is associated with the range of foods exploited. A larger animal can travel over a larger area and increase the potential range of prey used as compared with small predators (Gittleman 1985). The high consumption of small vertebrates (10.1-100.0 g) by wolves could result from its solitary hunting strategy as well as from a response to low density of ungulate populations in South America (Hershkovitz 1972). On the other hand, foxes are said to be opportunistic hunters (Brady 1979, Berta 1982, Facure \& Monteiro-Filho 1996) which may explain their intensive foraging of highly abundant insects (Dietz 1984).

\section{ACKNOWLEDGEMENTS}

We thank to Emydgio L. A. Monteiro-Filho for reviewing an earlier version of the manuscript. Antônio Cecílio Dias and the Instituto Florestal de São Paulo provided facilities at the Experimental Station of Itapetininga. Luís C. Sousa helped with the collection of faeces. Rogério R. Silva and Carlos Campaner identified some insects. Márcio R. C. Martins aided with identification of reptiles and Julio A. Lombardi identified some fruits. Alexandre Percequillo helped with some small mammals and Luis F. Silveira with some birds. Laura Buitrón revised the Spanish text. Financial support was provided by FAPESP.

\section{LITERATURE CITED}

ARAGONA M \& EZF SETZ (2001) Diet of the maned wolf, Chrysocyon brachyurus (Mammalia: Canidae), during wet and dry seasons at Ibitipoca State Park, Brazil. Journal of Zoology (London) 254: 131-136.

BESTELMEYER SV \& C WESTBROOK (1998) Maned wolf (Chrysocyon brachyurus) predation on pampas deer (Ozotoceros bezoarticus) in central Brazil. Mammalia 62: 591-595.

BERTA A (1982) Cerdocyon thous. Mammalian Species 186: 1-4.

BERNARDES AT, ABM MACHADO \& AB RYLANDS (1990) Fauna brasileira ameaçada de extinção. Fundação Biodiversitas/IBAMA, Belo Horizonte, Brasil. 62 pp.

BISBAL FJ \& J OJASTI (1980) Nicho trófico del zorro Cerdocyon thous (Mammalia, Carnivora). Acta Biologica Venezolana 10: 469-496.
BRADY CA (1979) Observations on the behaviour and ecology of the crab-eating fox (Cerdocyon thous). In: Eisenberg JF (ed) Vertebrate ecology in the northern Neotropics: 161-167. Smithsonian Institution Press, Washington, District of Columbia, USA.

BUENO AA, SCS BELENTANI \& JC MOTTA-JUNIOR (2002) Feeding ecology of the maned wolf, (Chrysocyon brachyurus Illiger, 1811) (Mammalia: Canidae) in the Ecological Station of itirapina, São Paulo State, Brazil. Biota Neotropica 2: 1-9. http:// www.biotaneotropica.cria.org.br/v2n2/en/ abstract?article+BNO1802022002.

CASTRO SA, SI SILVA, PL MESERVE, JR GUTIÉRREZ, LC CONTRERAS \& FM JAKSIC (1994) Frugivoría y dispersión de semillas de pimiento (Schinus molle) por el zorro culpeo (Pseudalopex culpaeus) en el Parque Nacional Fray Jorge (IV Región, Chile). Revista Chilena de Historia Natural 67: 169-176.

CARVALHO CT \& LEM VASCONCELLOS (1995) Disease, food and reproduction of the maned wolf Chrysocyon brachyurus (Illiger) (Carnivora, Canidae) in southeast Brazil. Revista Brasileira de Zoologia 12: 627-640.

DIETZ JM (1984) Ecology and social organization of the maned wolf (Chrysocyon brachyurus). Smithsonian Contributions to Zoology 392: 1-51.

DIETZ JM (1985) Chrysocyon brachyurus. Mammalian Species 234: 1-4.

EISENBERG JF \& KH REDFORD (1992) Mammals of the neotropics: the southern cone. University of Chicago Press, Chicago, Illinois, USA. 430 pp.

EMMONS LH (1987) Comparative feeding ecology of felids in a Neotropical rainforest. Behavioral Ecology and Sociobiology 20: 271-283.

FACURE KG \& AA GIARETTA (1996) Food habits of carnivores in a coastal Atlantic forest of southeastern Brazil. Mammalia 60: 499-502.

FACURE KG \& ELA MONTEIRO-FILHO (1996) Feeding habits of the crab-eating fox, cerdocyon thous (Carnivora, Canidae), in a suburban area of southeastern Brazil. Mammalia 60: 147-149.

GITTLEMAN JL (1985) Carnivore body size: ecological and taxonomic correlates. Oecologia 67: 540-554.

HERSHKOVITZ P (1972) The recent mammals of the Neotropical region: a zoogeographic and ecological review. In: Keast A, FC Erk \& B Glass (eds) Evolution, mammals and southern continents: 311431. State University of New York Press, Albany, New York, USA.

HILTON-TAYLOR C (compiler) (2000) 2000 IUCN red list of threatened species. International Union for the Conservation of Nature, Gland, Switzerland. $61 \mathrm{pp}$.

JAKSIC FM, JE JIMÉNEZ, SA CASTRO \& P FEINSINGER (1992) Numerical and functional response of predators to a long-term decline in mammalian prey at a semi-arid Neotropical site. Oecologia 89: 90-101.

JUAREZ KM \& J MARINHO-FILHO (2003) Diet, habitat use and home ranges of sympatric canids in central Brazil. Journal of Mammalogy 83

KREBS CJ (1999) Ecological methodology. Second edition. Addison Wesley Longman, Inc., Menlo Park, California, USA. 620 pp.

LANGGUTH A (1975) Ecology and evolution in the South American canids. In: Fox MW (ed) The wild canids: their systematics, behavioral ecology and evolution: 192-206. Van Nostrand Reinhold Co., New York, New York, USA.

MCDONALD DW \& O COURTENAY (1996) Enduring social relationship in a population of crab-eating 
zorro, Cerdocyon thous, in Amazon Brazil. Journal of Zoology (London) 239: 329-355.

MEDEL RG \& FM JAKSIC (1988) Ecología de los cánidos sudamericanos: una revisión. Revista Chilena de Historia Natural 61: 67-79.

MONES A \& J OLAZARRI (1990) Confirmación de la existencia de Chrysocyon brachyurus (Illiger) en el Uruguay (Mammalia: Carnivora: Canidae). Comunicaciones Zoológicas del Museo de Historia Natural de Montevideo (Uruguay) 174: 1-6.

MONTGOMERY GG \& Y LUBIN (1978) Social structure and food habits of the crab-eating fox in Venezuelan llanos. Acta Científica Venezolana 29 382-383.

MOTTA-JUNIOR JC (2000) Variação temporal e seleção de presas na dieta do lobo-guará, Chrysocyon brachyurus (Mammalia: Canidae), na Estação Ecológica de Jataí, Luiz Antônio, SP. Pp. 331-346. In: Santos JE \& JSR Pires (eds) Estudos integrados em ecossistemas. Estação Ecológica de Jataí. Volume 1. Rima Editora, São Carlos, Brasil.

MOTTA-JUNIOR JC, JA LOMBARDI \& SA TALAMONI (1994) Notes on crab-eating fox (Dusicyon thous) seed dispersal and food habits in Southeastern Brazil. Mammalia 58: 156-159.
MOTTA-JUNIOR JC, SA TALAMONI, JA LOMBARDI \& K SIMOKOMAKI (1996) Diet of the maned wolf, Chrysocyon brachyurus, in central Brazil. Journal of Zoology (London) 240: 277-284.

MOTTA-JUNIOR JC \& K MARTINS (2002) The frugivorous diet of the maned wolf, Chrysocyon brachyurus, in Brazil: ecology and conservation. Pp. 291-303. In: Levey DJ, WR Silva \& M GALETTI (eds). Seed Dispersal and Frugivory: Ecology, Evolution and Conservation. Wallingford, Oxfordshire: CABI Publishing, UK.

NOWAK RM (1999) Walker's mammals of the world. Volume 2. Sixth edition. John Hopkins University Press, Baltimore, Maryland, USA. 1,936 pp.

OLMOS F (1993) Notes on the food habits of Brazilian caatinga carnivores. Mammalia 57: 126-130.

RODRIGUES FHG, A HASS, ACR LACERDA \& RLSC GRANDO (1998) Biologia e conservação do loboguará na Estação Ecológica de Águas Emendadas, Anais do Seminário "Pesquisa em Unidades de Conservação" (Brasil) 1: 28-42.

ROSENZWEIG M (1966) Community structure in sympatric carnivora. Journal of Mammalogy 47: 602-612.

ZAR JH (1984) Biostatistical analysis. Second edition. Prentice-Hall, Englewood Cliffs, New Jersey, USA. 718 pp. 


\section{APPENDIX 1}

List of plant and animal items found in the maned wolf's and the crab-eating fox's diets in the Experimental Station of Itapetininga, São Paulo, Brazil. Numerical data are respectively mean weight $(\mathrm{g})$ in parentheses; occurrence; number of individual animals; estimated biomass $(\mathrm{g})$

Lista de plantas y animales encontrados en las dietas del aguara guazú y del zorro del monte en la Estación Experimental de Itapetininga, São Paulo, Brasil. Los datos numéricos son, respectivamente, el peso promedio (g; en paréntesis); la ocurrencia, el número de animales individuales y la biomasa estimada $(\mathrm{g})$

\begin{tabular}{llllllll}
\hline Food item & \multicolumn{3}{c}{ Chrysocyon brachyurus } & & & Cerdocyon thous \\
\cline { 2 - 3 } \cline { 5 - 7 } & Occurrence & $\begin{array}{l}\text { Number of } \\
\text { individuals }\end{array}$ & $\begin{array}{c}\text { Biomass } \\
(\mathrm{g})\end{array}$ & & Occurrence & $\begin{array}{l}\text { Number of } \\
\text { individuals }\end{array}$ & Biomass $(\mathrm{g})$ \\
\hline
\end{tabular}

Fruits

Solanum lycocarpum

Solanum sisymbriifolium

Solanum sp. 1

Syagrus romanzoffiana

Syagrus sp.

Alagoptera sp.

Palmae

Duguetia furfuracea

Annona cf. crassiflora

Annonaceae

Campomanesia sp.

Psidium sp.

Bromelia antiacantha

Pouteria sp.

Lauraceae

Melancium campestre

Curcubitaceae

Citrus sp.

Peritassa campestris

Unidentified seeds (\#1 to \#"6)

Grasses and leaves

Lizards, snakes, frogs, and fish

Unidentified fish (100.0)

Anura Leptodactylidae A (22.9)

Anura Bufonidae ${ }^{\mathrm{A}}$ (8.8)

Unidentified snakes $(*)$

Colubridae (*)

Colubridae sp. 1 (22.0)

Colubridae sp. 2 (32.3)

Small Viperidae (33.2)

Botrops sp. (55.2)

Tupinambis cf. merianae (998.3)

Mabuya sp. ${ }^{\mathrm{A}}$ (10.0)

Birds

Rynchotus rufescens (200.0)

Tinamidae (160.0)

Volatinia jacarina (10.0)

Troglodytidae (10.0)

Passeriforme (20.0)

Emberizidae (15.0)

Gallus gallus (400.0)

Unidentified small birds (20.0)
400.0 


\begin{tabular}{|c|c|c|c|c|c|c|}
\hline \multirow[t]{2}{*}{ Food item } & \multicolumn{3}{|c|}{ Chrysocyon brachyurus } & \multicolumn{3}{|c|}{ Cerdocyon thous } \\
\hline & Occurrence & $\begin{array}{l}\text { Number of } \\
\text { individuals }\end{array}$ & $\begin{array}{l}\text { Biomass } \\
(\mathrm{g})\end{array}$ & Occurrence & $\begin{array}{l}\text { Number of } \\
\text { individuals }\end{array}$ & Biomass $(\mathrm{g})$ \\
\hline Unidentified medium birds $(50.0)$ & 14 & 11 & 550.0 & 1 & 1 & 50.0 \\
\hline Unidentified large birds (100.0) & 1 & 1 & 100.0 & 1 & 1 & 100.0 \\
\hline Eggs (10.0) & 7 & 7 & 70.0 & 1 & 1 & 10.0 \\
\hline
\end{tabular}

Opossums

Didelphis albiventris (1189.0)

7

$9 \quad 10,701.0$

Armadillos and anteaters

Tamandua tetradactyla ${ }^{\mathrm{B}}(1500.0)$

Dasypus aff. novemcinctus (2000.0)

Dasypus sp. (2000.0)

Euphractus sexcinctus $^{\mathrm{B}}(2000.0)$

Dasypodidae (2000.0)

Rodents

Calomys tener (16.0)

Oligoryzomys nigripes (16.5)

Bolomys lasiurus (41.5)

Clyomys bishopi (277.3)

Holochilus brasiliensis (326.0)

Cavia aperea (435.0)

Unidentified small mammal (20.0)

Unidentified mammal 1 (16.0)

Unidentified mammal 2 (41.5)

Unidentified mammal 3 (277.3)

Unidentified mammal 4 (435.0)

Unidentified medium sized mammal ${ }^{\mathrm{C}}(2700.0)$

55

54

29

26

5

24

61

6

3

1

3

Rabbits

Sylvilagus brasiliensis (933.8)

Deer

Mazama sp. ${ }^{\mathrm{C}}$ juvenile (16300.0)

Carnivores

Nasua nasua ${ }^{\mathrm{B}}$ (4000.0) 


\begin{tabular}{|c|c|c|c|c|c|c|}
\hline \multirow[t]{2}{*}{ Food item } & \multicolumn{3}{|c|}{ Chrysocyon brachyurus } & \multicolumn{3}{|c|}{ Cerdocyon thous } \\
\hline & Occurrence & $\begin{array}{l}\text { Number of } \\
\text { individuals }\end{array}$ & $\begin{array}{c}\text { Biomass } \\
(\mathrm{g})\end{array}$ & Occurrence & $\begin{array}{l}\text { Number of } \\
\text { individuals }\end{array}$ & Biomass $(\mathrm{g})$ \\
\hline
\end{tabular}

Praying mantes

Mantidae (0.61)

Beetles

\section{Scarabaeidae}

Dichotomius anaglypticus (0.85)

Dichotomius sp. (0.85)

Bothynus sp. (1.0)

Dynastinae (1.74)

10

17

Melolontinae (0.5)

Rutelinae (0.5)

Scarabaeinae (1.84)

Scarabaeidae sp. 1 (1.0)

Hydrophilidae (0.7)

Erotylidae (0.5)

Geotrupidae (0.2)

Tenebrionidae (0.9)

Carabidae

Megacephalini (0.5)

Cicindelinae (0.19)

Unidentified Carabidae (0.25)

Cerambycidae (1.45)

Cucujidae (0.4)

Unidentified Coleoptera 1 to 5 (0.6)

Giant water bugs

Belastomatidae sp. 1 (1.5)

Belastomatidae sp. 2 (1.5)

Termites

Unidentified sp. $1(0.05)$

Unidentified sp. 2 (0.08)

Ants and wasps

Formicidae

Pheidole sp. (0.025)

Camponotus sp. (0.02)

Myrmecinae (0.025)

Ponerinae $(0.22)$

Unidentified Formicidae (0.22)

Vespidae (0.08)

Cockroaches

Parahormetica sp. (1.81)

Blattaria sp. (0.8)

\begin{tabular}{|c|c|c|c|c|c|}
\hline & & & 1 & 18 & 0.45 \\
\hline \multirow[t]{3}{*}{1} & 2 & 0.04 & 2 & 167 & 3.34 \\
\hline & & & 13 & 50 & 1.24 \\
\hline & & & 1 & 3 & 0.66 \\
\hline 3 & 10 & 2.2 & 9 & 101 & 22.2 \\
\hline \multirow[t]{3}{*}{35} & 595 & 47.6 & & & \\
\hline & & & 2 & 4 & 7.24 \\
\hline & & & 1 & 1 & 0.8 \\
\hline & 1,535 & $230,208.2$ & 429 & 2,899 & $18,660.3$ \\
\hline
\end{tabular}

Total

1,344

1,535

81

85.0

7.8

1.0

\section{1}

1

47

39.9

6

11.0

18

6.3

1.7

1.0

10.5

1.8

7.0

11.2

0.5

1.0

0.9

1.0

0.6

3.75

31.9

0.81

12.6

3

11

6.6

$\begin{array}{llr}2 & 9 & 13.5 \\ 1 & 3 & 4.5\end{array}$

Notes: All weights are for adults except when indicated and from data field; ${ }^{\mathrm{A}} \mathrm{M}$. Martins (personal communication); ${ }^{\mathrm{B}}$ Nowak (1999); ${ }^{C}$ Eisenberg \& Redford (1999); (*) body masses were estimated by measuring larger width of ventral scale from faeces and applying this as the independent variable $(\mathrm{X})$ to the regression equation: $\log \mathrm{Y}=2.669 \log \mathrm{X}-1.540$ where $\mathrm{Y}$ is the dependent variable body mass $\left(\mathrm{R}^{2}=0.999, \mathrm{P}<0.0001, \mathrm{n}=5\right.$ snakes collected in the area) 